\title{
The Depression Categories of Adolescent with Beta-Thalassemia Major
}

\author{
Wafa Fida Az-zahra, Ai Mardhiyah, Ikeu Nurhidayah \\ Faculty of Nursing, Universitas Padjadjaran \\ Email:wafafidaazz@gmail.com
}

\begin{abstract}
The adolescent with beta-thalassemia major is experiencing both physical and psychological problems, one of them is depression because of suffering a chronic illness. Depression in the adolescent with thalassemia would affect patients' quality of life and disturb the treatment processes. The purpose of this study was to determine the level of depression in the adolescent with beta-thalassemia major in the Sumedang public hospital. This research was a quantitative descriptive study. The population in this study was adolescents aged 13-20 years with a beta-thalassemia major in the policlinic of Thalassemia in Sumedang Public Hospital. The sample was determined by using total sampling technique, therefore 35 people involved in this study. Data were collected using standard instrument Beck Depression Inventory II. Data were analyzed using frequency distribution. The results of this study showed that adolescent with beta-thalassemia major age 13-20 years in the Sumedang public hospital had $45.7 \%$ minimal depression, $20 \%$ mild depression, $25.7 \%$ moderate depression, and $8.6 \%$ severe depression. It can be concluded that the majority of the adolescent with beta-thalassemia major in the hospital have minimal depression and the highest depression type is moderate depression. Nurses were expected to provide psychological services for consultation and periodic depression screening of adolescent with thalassemia.
\end{abstract}

Keywords: adolescence, beta thalassemia major, depression 
Wafa Fida Az-Zahra: The Depression Categories of Adolescent with Beta-Thalassemia Major

\section{Introduction}

Thalassemia is a serious illness in the Eastern Mediterranean region, especially Southeast Asia and India. Around 300 million people with thalassemia worldwide and 55 million of them live in SoutheastAsia(Adib-Hajbaghery, Ahmadi, \& Poormansouri, 2015). Indonesia is a country in Southeast Asia with a high risk of thalassemia. According to WHO, the incidence of thalassemia carriers in Indonesia ranges from $6-10 \%$, it means that every 100 people there are 6-10 people are carriers of thalassemia. According to Ruswadi, chairman of the Indonesian Thalassemia Foundation, in 2016 the number of patients with major betathalassemia reached 7,238 patients who were registered from hospitals in Indonesia. West Java Province is the province with the highest number of thalassemia sufferers in Indonesia. The number of thalassemia patients in West Java reaches $42 \%$ of all thalassemia sufferers in Indonesia (Putra, 2016). Meanwhile, in the Sumedang Regional General Hospital located in Sumedang Regency, West Java, the number of patients in the policlinic of thalassemia is increasing every year, in 2013 the number of thalassemia patients was 116 patients and in 2017 it increased to 140 patients.

Thalassemia is a hereditary red blood cell disorder. Thalassemia requires transfusion to save patients' life (Santos et al., 2015). Beta major thalassemia has severe anemia symptoms that require regular blood transfusions (Wong, 2009). People with beta major thalassemia experience physical and psychological problems. Physical problems such as growth problems, puberty delayed, deformity due to thalassemia change the physical appearance and body image of the patient. Physical conditions cause psychological problems, such as patients becoming inferior (Adib-Hajbaghery et al., 2015). Other psychological problems such as anxiety, depression, despair, and difficulties in social relationships are also experienced by people with major beta-thalassemia (Yengil et al., 2014).

Adolescence is a transition phase between childhood and adulthood. Adolescence is a time when seeking self-identity and frequent confusion of roles (Kyle \& Carman, 2014). Teenagers experience various changes, ranging from physical, psychological, and social. Normal adolescence is when they try to be independent. Teenagers with thalassemia try to live in normal life and they try hard to deal with the deadly nature of their illness. They need more attention and planning. At the same time, adolescents are looking for independence and identity, but for whom with thalassemia, they are limited by their illness and possible complications (Koutelekos \& Haliasos, 2013)

Teenagers with thalassemia are at risk of psychological disorders, they may be affected by this chronic illness. They are very careful because of this disease that is harmful to their health (Koutelekos \& Haliasos, 2013). This thalassemia affects their emotional conditions, they become inferior due to a different physical appearance with normal teens (Indonesian Pediatrician Association [IDAI], 2013). Thus, they face complex problems in their lives that may cause depression.

Depression is a psychiatric disorder in the form of mood disorders with the main symptoms of sadness and loss of interest and pleasure (Sadock, 2010). According to the DSM-V, a severe depressive is when there are five or more symptoms, at least occur for 2 weeks, and there is a change in function than before. According to Beck (1967 in Lubis, 2009), there are four categories of depression manifestations, including emotional manifestations, cognitive manifestations, motivational manifestations, and physical manifestations. Health workers should be a concern of thalassemia teenagers with depressive symptoms (Koutelekos \& Haliasos, 2013).

The research conducted by Shaligram et al. (2007), showed that $44 \%$ of thalassemia teenagers had psychological problems, including anxiety $67 \%$, emotional problems, especially depression, $62 \%$ and behavioral problems $49 \%$. Another study conducted by Behdani et al. (2015), regarding depression in adolescents with thalassemia, showed that patients with thalassemia experienced depression of about 26.7\%, significant discharge compared to healthy children. According to Pattanashetti et al. (2017), the prevalence of depression in thalassemia reached $41.94 \%$ with the majority of them 
had mild depression.

Beta major thalassemia patients have experienced depression and anxiety conditions. These may because of this disease has a negative impact on the physical, mental, and quality of life of patients. Psychological counseling in thalassemia patients is beneficial for patients' medication adherence and quality of life (Yengil et al., 2014). Nurses have responsibilities in providing nursing care for patients. The role of nurses as health workers are dealing with teenage thalassemia patients from various aspects including biological needs such as blood transfusions and iron chelation therapy, psychiatric disorders, and improves psychosocial adaptation to their illness (Koutelekos \& Haliasos, 2013). Nurses are expected to be able to help teenagers with thalassemia to improve strategies so they can adapt to psychosocial problems. In addition, it is important for nurses to carry out early detection of depression to prevent depression in teenage patients with beta major thalassemia.

Based on the results of a preliminary study, researchers conducted interviews with five teenage patients with beta major thalassemia in Sumedang Hospital. Patients said they often feel sad and scared. The patient also feels shy and doesn't have friends, sometimes gets ridicule from his friends. The patient also said he was angry, had difficulty concentrating, sometimes had difficulty sleeping, and was afraid to get married. In addition, they also said that they do not routinely take iron chelation drugs, because patients feel bored taking medication and uncomfortable with the side effects.

Based on the description, the researcher was interested in examining depression in adolescents with beta major thalassemia in Sumedang General Hospital. The purpose of this study was to describe depressions in adolescents with major beta-thalassemia in Sumedang General Hospital.

\section{Method}

This study was a quantitative descriptive study with a single variable namely depression in adolescents with beta major thalassemia in Sumedang General Hospital. The population in this study was all teenage patients with beta major thalassemia in the policlinic of thalassemia. The number of teenage patient with thalassemia was 35 people in 2017. Samples were chosen using the total sampling technique, 35 teenagers involved in this study.

The instrument of this study used the Beck Depression Inventory-II from Aaron T. Beck. BDI-II measured depression with depressive symptoms. BDI-II consists of 21 statement items include: mood, pessimism, past failure, loss of pleasure, feelings of guilt, feeling of being punished, disliking oneself, accusations of oneself, thoughts / desires of suicide, crying, unable to rest, loss of interest, doubt, insignificance, loss of energy, changes in sleep patterns, irritability, loss of appetite, difficulty concentrating, fatigue, and loss of interest in sex. Each item was rated from 0 to 3 , then the value of each item was added up and categorized according to the level of depression: no depression / normal 0-13, mild depression 14-19, moderate depression 20-28, and severe depression 29-63.

The instrument has been tested for validity and reliability. Robinson (1991 in Aditomo \& Retnowati, 2004) has tested the validity of BDI in Indonesia with results ranging from 0.6 to 0.9 . In the research conducted by Hasanah (2015), the instrument was conducted face validity test to 4 respondents with the results of the instrument easily understood by respondents. Then, the researcher also tested the validity with content validity to the supervisor and conducted face validity to 5 respondents with the results that questions easily understood by the respondents. Whereas, for reliability testing, BDI has been adapted and tested for reliability several times in Indonesia. Prabandari (in Aditomo \& Retnowati, 2004), found that the Indonesian version of BDI reliability was 0.93 . From the results of the validity and reliability test, the instrument is valid and reliable.

This research has received ethical approval from the Research Ethics Commission of Padjadjaran University with letter number 634 /UN6.KEP/EC/2018. After obtaining ethical approval, researchers submitted research permits at Sumedang General Hospital. After obtaining research permission at Sumedang 
Wafa Fida Az-Zahra: The Depression Categories of Adolescent with Beta-Thalassemia Major

Hospital with letter number 800/352 / Diklat / 2018, researchers conducted research at the policlinic of Talasemia in Sumedang General Hospital. Data analysis is presented in the form of frequency distribution and percentage. Analysis of data has done to obtain the level of depression in adolescent thalassemia by calculating the total scores of each respondent then categorized according to the level of depression.

\section{Results}

Characteristics of respondents showed the adolescent ages in the middle and final adolescents categories as many as 13 people. Most of the respondents were female teenagers $(57.1 \%)$. The most recent education of respondents was elementary school graduates, which was around 51.4\%. Respondents who had a weekly blood transfusion schedule were $37.1 \%$. Almost all the respondents lived with their parents, 33 people. Most respondents had mothers and fathers $(77.1 \%)$. Most respondents did not have families with severe thalassemia.

Table 1. Characteristics of Respondents

\begin{tabular}{|c|c|c|}
\hline Characteristics & Frequency (f) & Percentage $(\%)$ \\
\hline \multicolumn{3}{|l|}{ Ages } \\
\hline Early adolescent (13-14 years) & 9 & 25.7 \\
\hline Middle adolescent (15-17 years) & 13 & 37.1 \\
\hline Final adolescent (18-20 years) & 13 & 37.1 \\
\hline \multicolumn{3}{|l|}{ Gender } \\
\hline Male & 15 & 42.9 \\
\hline Female & 20 & 57.1 \\
\hline \multicolumn{3}{|l|}{ Education } \\
\hline Elementary school & 18 & 51.4 \\
\hline Junior high school & 10 & 28.6 \\
\hline Senior high school & 7 & 20 \\
\hline \multicolumn{3}{|l|}{ Blood transfusion schedule } \\
\hline Once a week & 13 & 37.1 \\
\hline Twice a week & 12 & 34.3 \\
\hline Third times a week & 2 & 5.7 \\
\hline Once a month & 8 & 22.9 \\
\hline \multicolumn{3}{|l|}{ Stay with } \\
\hline Mother-Father & 33 & 94.2 \\
\hline Stepparents & $\mathbf{0}$ & $\mathbf{0}$ \\
\hline $\begin{array}{c}\text { Grandma/grandpa, Brother/ } \\
\text { sister }\end{array}$ & 1 & 2.9 \\
\hline Aunty/aunt & 1 & 2.9 \\
\hline \multicolumn{3}{|l|}{ History of family } \\
\hline Complete father-mother & 27 & 77.1 \\
\hline Parents already passed away & 7 & 20 \\
\hline Divorce & 1 & 2.9 \\
\hline \multicolumn{3}{|l|}{ History of thalasemia in family } \\
\hline None & 23 & 65.7 \\
\hline One & 10 & 28.6 \\
\hline Two & 1 & 2.9 \\
\hline
\end{tabular}


Wafa Fida Az-Zahra: The Depression Categories of Adolescent with Beta-Thalassemia Major

$>\mathbf{3}$ form family members

1

2.9

Table 2. Depression category in adolescents with Thalassemia

\begin{tabular}{|c|c|c|}
\hline Depression category & Frequency (f) & Percentage (\%) \\
\hline Normal & 16 & 45.7 \\
\hline Mild & 7 & 20 \\
\hline Moderate & 9 & 25.7 \\
\hline Severe & 3 & 8.6 \\
\hline
\end{tabular}

This study showed that 16 people $(45.7 \%)$ were categorized as normal, 7 people $(20 \%)$ were categorized as mild depression, 9 people $(25.7 \%)$ were categorized as moderate depression, and 3 people $(8.6 \%)$ categorized as severe depression (Table 2.).

\section{Discussion}

The results showed that almost half of the respondents were normal or not depressed $(45.7 \%)$. However, when we summed up from mild, moderate, and severe depression, the majority of respondents experienced depression (54.3\%). According to Shaligram et al. (2007), 44\% of teenagers with thalassemia have psychological and emotional problems, especially depression, as much as $62 \%$. In line with the research conducted by Yahia \& Adel (2013), states that depression in thalassemia is significantly higher. Adib-Hajbaghery et al. (2015), states that people with thalassemia experience less than optimal physical development, such as late puberty and body deformities, it may be caused physical appearance and body image of the thalassemia person apparently different with the normal teenagers. This can lead to psychological problems such as depression. In inline with the research of Yengil et al. (2014) which states that thalassemia sufferers experience psychological problems such as anxiety, depression, and despair. These psychological problems can affect emotional conditions and difficulties in social relations.

In this study, respondents' age of middle and late adolescents were 13 patients each. Normally, adolescents experience had various changes including physical, psychological, and social. According to Naderi et al. (2012), psychological problems in thalassemia patients as much as $78 \%$ are in the late teenage group (18-21 years). It is characterized by more irritability or sensitivity due to changes in life and puberty. Adolescence is also a time when looking for an identity and trying to be independent. However, in adolescents with thalassemia, they focus on managing a life-threatening illness (Koutelekos \& Haliasos, 2013). Baraz, Miladinia, \& Mosavinouri (2016) stated that teenagers with thalassemia do not experience the development of adulthood like a healthy teenager, this is the difference between healthy adolescents and adolescent with thalassemia. According to Behdani et al. (2015), depression in teenage children with thalassemia was around $26.7 \%$, seen as significant compared to healthy. Table 1, the number of male respondents was around $42.9 \%$ and women $(57.1 \%)$. The results of the study showed that 19 respondents who were depressed, 13 respondents were female. This is in accordance with the research of Maughan et al. (2013) that depression increased in female sex compared to men. Young women often feel anxious about life, and they are less able to control the environment compared to men (Stuart, 2016).

The schedule of blood transfusion of teenage thalassemia patients in Sumedang General Hospital is mostly once a week (37.1\%). Thalassemia is a hereditary blood disorder that requires lifelong medication adherence (Mednick et al., 2010). However, continuous blood transfusions have side effects, including iron buildup. From these side effects, complications may occur in thalassemia patients. Patients may feel anxiety due to complications that occur. This may cause psychological problems and emotional burden on patients so that it would affect patients' quality of life (Thavorncharoensap et al., 2010; Mazzone et al., 2009).

The characteristics of the respondents 
related to the family were that the majority of them $(94.2 \%)$ lived with their biological parents and most (77.1\%) of them have parents. According to Koutelekos \& Haliasos (2013), family conditions such as death, divorce, family conflict, and economic conditions would reduce the quality of family relationships. This would lead to depression. According to Maughan et al. (2013), a lot of pressure in families would influence children depression. The results of this study found that most patients have parents and they live with them. From these conditions, it is expected that the family would become a support system for teenage patients. However, this study was not examined in depth about conflicts in the family of thalassemia patients.

The results showed that most respondents had high scores related to energy loss and tiredness or fatigue. This in line with Sumiarsih's (2016) study found that thalassemia patients experienced physical weakness, felt weak, and tired. According to Yengil et al. (2014), thalassemia patients with depressive symptoms describe low selfesteem and have a lack of energy to carry out activities that cause a negative impact on the patient's physical and mental quality.

Respondents score was high on statements ofloss of pleasure, guilt, and failure. According to Aji et al (2009), the psychosocial function of thalassemia patients is disrupted. The different physical appearance of thalassemia patients with healthy children influences the child's personality development. At the age of adolescence, adolescents paid attention to their physical appearance. Whereas, in thalassemia patients, they experience slow physical development that changes their appearance. This raises problems on social relations with peers and affects heterosexual performance and relationships (Koutelekos \& Haliasos, 2013). This may be the cause of lost happiness, guilt, and feeling unsuccessful in thalassemia patients.

The results showed that more than half of the respondents $(54.3 \%)$ experienced mild to severe depression, so special attention was needed to the psychology of adolescent patients aged 13-20 years with beta major thalassemia in Sumedang General Hospital. From the results of this study, the efforts that can be done by nurses and other health workers is to provide psychological services for adolescent patients with thalassemia including discussion, and consultation about their conditions. In addition, nurses are also expected to be able to screen depression in a sustainable manner and conduct further examinations for patients who are depressed and refer them to experts. People with major beta-thalassemia need psychosocial support to improve medication adherence and strengthen strategies so that everyday life is better so it would improve the quality of life of patients (Aydinok et al., 2005; Mazzone et al., 2009). Support and motivation from nurses and families to adolescent patients would prevent depression and improve quality of life. In addition, the family is also expected to be a support system for teenagers with thalassemia. Family support plays an important role in improving the quality of life of patients. According to Pranajaya \& Nurchairina (2016), there is a significant relationship between parental support and the quality of life of thalassemia patients.

The limitation of this study is that this study was categorized depression through screening using questionnaires, and no observation of patients' behavior so that it could not describe the patient's psychological symptoms.

\section{Conclusion}

The results of this study indicate that almost half of the adolescents with a major beta-thalassemia age 13-20 years in Sumedang General Hospital were in normal psychological condition, however more than half of them had mild to severe depression. Depressive symptoms include losing their happiness, feeling unsuccessful, feeling guilty, losing energy, and feeling tired. This is likely due to the disease, and psychological problems that result from the changes of physical appearance, physical weakness, worries about the condition of the disease, and shame. Nurses and health workers are expected to provide psychological services for adolescent patients with thalassemia including discussion and consultation regarding the patient's condition. In addition, it is expected to be able to screen depression 
Wafa Fida Az-Zahra: The Depression Categories of Adolescent with Beta-Thalassemia Major

continuously and refer patients who are depressed to experts. Families are expected to motivate and provide psychosocial support to teenagers with thalassemia by providing positive thoughts related to the conditions and diseases they experience.

\section{References}

Adib-Hajbaghery, M., Ahmadi, M., \& S, P. (2015). Health-Related Quality of Life, Depression, Anxiety, and Stress in Patients with Beta-Thalassemia Major. Iranian Journal of Pediatric Hematology and Oncology, 5(4), 193-205.

Aditomo, A. \& Retnowati, S. (2004). Perfeksionisme, Harga Diri, dan Kecenderungan Depresi pada Remaja Akhir. Jurnal Psikologi, 1-14.

Aji, D. N., Silman, C., Aryudi C., Cynthia, Centauri, Andalia, D., Astari, D., Pitaloka, D., Wawolumaya, C., Sekartini, R., Pustika, A. (2009). Faktor-faktor yang Berhubungan dengan Kualitas Hidup Pasien Thalassemia Mayor di Pusat Thalassemia Departemen Ilmu Kesehatan Anak RSCM. Sari Pediatri, 85-89.

Aydinok, Y., Erermis, S., Bukusoglu, N., Yilmazi, D., \& Solak, U. (2005). Psychosocial implications of Thalassemia Major. Pediatrics International, 47(1), 84-89. https://doi. org/10.1111/j.1442-200x.2004.02009.x

Baraz, S., Miladinia, M., \& Mosavinouri, E. (2016). A Comparison of Quality of Life between Adolescences with Beta Thalassemia Major and their Healthy Peers. International Journal of Pediatrics, 4(1), 1195-1204. https://doi.org/10.22038/ijp.2016.6228

Beck, A. T.. (2006). Depression: Causes and Treatment. Philadelphia, Pennsylvania: University of Pennsylvania Press.

Behdani, F., Badiee, Z., Hebrani, P., Moharreri, F., Badiee, A. H., Hajivosugh, N., Akhavanrezayat, A. (2015). Psychological aspects in children and adolescents with major thalassemia: A case-control study.
Iranian Journal of Pediatrics, 25(3), 0-7. https://doi.org/10.5812/ijp.25(3)2015.322

Carman, T. K. (2014). Buku Praktik Keperawatan Pediatrics. Jakarta: EGC.

Hasanah, Siti Amanatun. (2015). Gambaran Tingkat Depresi pada Pasien Kanker Serviks di RSUP Dr. Hasan Sadikin Bandung.

IDAI. (2013, September 10). Ikatan Dokter Anak Indonesia. Retrieved from Kualitas Hidup Remaja dengan Kondisi Penyakit Kronis: http://www.idai.or.id/artikel/seputarkesehatan-anak/kualitas-hidup-remajadengan-kondisi-penyakit-kronis.

Khamoushi, F., Ahmadi, S. M., KaramiMatin, B., Ahmadi-Jouybari, T., MirzaeiAlavijeh, M., Ataee, M., Mahboubi, M. (2015). Prevalence and Socio-Demographic Characteristics Related to Stress, Anxiety, and Depression among Patients with Major Thalassemia in the Kermanshah Country. Journal of Biology and Today's World, 7984. DOI: 10.15412/J.JBTW. 01040304.

Khurana, A., Katyal, S., \& Marwaha, R. K. (2006). The psychosocial burden in thalassemia. Indian Journal of Pediatrics, 73(10), 877-80. https://doi.org/10.1007/ BF02859278.

Koutelekos, J., \& Haliasos, N. (2013). Depression and thalassemia in children, adolescent, and adults. Health Science Journal, 7, 239-246.

Lubis, N. L. (2009). Depresi Tinjauan Psikologi Edisi Pertama. Jakarta: Kencana.

Major, T., Ghanizadeh, A., Khajavian, S., \& Ashkani, H. (2006). Prevalence of Psychiatric Disorders, Depression, and. Journal of Pediatric Hematologic Oncology, 28(12), 781-784.

Maughan, B., Collishaw, S., \& Stringaris, A. (2013). Depression in childhood and adolescence. Journal of the Canadian Academy of Child and Adolescent Psychiatry, 22(1), 35-40. https://doi.org/10.1093/ $\mathrm{sw} / 32.6 .512$. 
Wafa Fida Az-Zahra: The Depression Categories of Adolescent with Beta-Thalassemia Major

Mazzone, L., Battaglia, L., Andreozzi, F., Romeo, M. A., \& Mazzone, D. (2009). Emotional impact in $\beta$-thalassemia major children following cognitive-behavioral family therapy and quality of life of caregiving mothers. Clinical Practice and Epidemiology in Mental Health, 5, 1-6. https://doi.org/10.1186/1745-0179-5-5.

Mednick, L., Yu, S. S., Trachtenberg, F., Xu, Y., Kleinert, D. A. DA, Giardina, P. P. J., ... Thalassemia Clinical Res Network, (2010). Symptoms of depression and anxiety in patients with thalassemia: Prevalence and correlates in the thalassemia longitudinal cohort. American Journal of Hematology, 85(10), 802-805. https://doi.org/10.1002/ ajh.21826.

Naderi, M., Hormozi, M. R., Ashrafi, M., \& Emamdadi, A. (2012). Evaluation of mental health and related factors among patients with Beta-thalassemia major in South East of Iran. Iranian Journal of Psychiatry, 7(1), $47-51$

Nursalam. (2008). Konsep dan Penerapan Metodologi Penelitian Ilmu Keperawatan Pedoman Skripsi, Tesis, dan Instrumen Penelitian Keperawatan. Jakarta: Salemba Medika.

Pattanashetti, M., Mugali, J., \& Pattanashetty, N. (2017). A Study of Severity of Depression in Thalassemia Patients, 4(2).

Pranajaya, R. dan Nurchairina. (2016). Faktor yang Berhubungan dengan Kualitas Hidup Anak Thalasemia. Jurnal Keperawatan, 130139.

Putra, E. W. (2016). Jumlah Penderita Talasemia Terus Meningkat. Banyumas: Republika.

Sadock, B. J. (2010). Kaplan \& Sadock Buku Ajar Psikiatri Klinis Ed. 2. Jakarta: EGC.

Santos, D. G. Z. Z. (2015). Pathophysiology and Treatment of Beta-Thalassemia: Investigations of Heme Oxygenase 1 and Its Inhibitors. Blood, 2269-2277.
Shafiee, A., Nazari, S., Jorjani, S., Bahraminia, E., \& Sadeghi-Koupaei, M. (2014). Prevalence of depression in patients with $\beta$-thalassemia as assessed by the Beck's depression inventory. Hemoglobin, 38(4), 289-291. https://doi.org/10.3109/03630269. 2014.929008.

Shaligram, D., Girimaji, S. C., \& Chaturvedi, S. K. (2007). Psychological problems and quality of life in children with thalassemia. The Indian Journal of Pediatrics, 74(8), 727730. https://doi.org/10.1007/s12098-0070127-6.

Stuart, G. W. (2016). Prinsip dan Praktik Keperawatan Kesehatan Jiwa Stuart Edisi Indonesia. (B. A. Pasaribu, Ed.) Singapore: Elsevier..

Sumiarsih, D. (2016). Kualitas Hidup Penderita Thalasemia Beta Mayor di Ruang Cempaka RSUD dr. Soediran Mangun Soemarso Wonogiri.

Thavorncharoensap, M., Torcharus, K., Nuchprayoon, I., Riewpaiboon, A., Indaratna, K., \& Ubol, B. (2010). Factors affecting health-related quality of life in Thai children with thalassemia, 1-10. https://doi. org/10.1186/1471-2326-10-1

Videbeck, Sheila L. (2008). Buku Ajar Keperawatan Jiwa. Jakarta: EGC.

Wahidayat, I. (2003). Thalassemia dan Permasalahannya di Indonesia. Sari Pediatri, 2-3.

Wong, D. L. (2008). Buku Ajar Keperawatan Pediatrik Wong, Ed. 6, Vol 1. Jakarta: EGC.

Wong, D. L. (2009). Buku Ajar Keperawatan Pediatrik Wong, Ed. 6, Vol. 2. Jakarta: Buku Kedokteran EGC.

Yahia, S., \& Adel, M. (2013). Predictors of anxiety and depression in Egyptian thalassemic patients: A single center study, 604-609. https://doi.org/10.1007/s12185013-1322-z. 
Wafa Fida Az-Zahra: The Depression Categories of Adolescent with Beta-Thalassemia Major

Yengil, E., Acipayam, C., Kokacya, M. H., Kurhan, F., Oktay, G., \& Ozer, C. (2014). Anxiety, depression, and quality of life in patients with beta-thalassemia major and their caregivers. International Journal of Clinical and Experimental Medicine, 7(8), 2165-2172. 